\title{
Comparing the Shear Bond Strength of Six Adhesive Systems to Enamel of Primary Teeth
}

Farokh Gisovar $E^{1 *}$, Hedayati $\mathbf{N}^{2}$, Shadman $\mathbf{N}^{3}$ and Shafiee $\mathrm{L}^{1}$

${ }^{1}$ Pediatric Dentistry Group, Kerman University of Medical Sciences, Iran

${ }^{2}$ Pediatric Dentistry Group, Rafsanjan University of Medical Sciences, Rafsanjan, Iran

${ }^{3}$ Restorative and Cosmetic Dentistry Group, Kerman University of Medical Sciences, Iran

*Corresponding author: Elham Farokh Gisour, Pediatric Dentistry Group, Dentistry Faculty, Kerman University of Medical Sciences, Iran, Tel: +989151689178; E-mail: e_1379farokh@yahoo.com

Rec Date: Jun 08, 2014; Acc Date: Nov 29, 2014; Pub Date: Dec 05, 2014

Copyright: @ 2014 Gisour EF, et al., This is an open-access article distributed under the terms of the Creative Commons Attribution License, which permits unrestricted use, distribution, and reproduction in any medium, provided the original author and source are credited.

\section{Abstract}

Aim and goals: The aim of this study was to evaluate and compare the shear bond strength of six adhesive systems to enamel of primary teeth.

Method: This experimental in vitro study was performed on 72 extracted primary molars. The teeth were randomly divided into six groups. In each group one of the adhesives; Tetric N-Bond, AdheSE, AdheSE One F, Single Bond 2, SE Bond, and Adper Prompt L-Pop, were used. After preparing the flat enamel surfaces on buccal or lingual and applying adhesives, composite was adhered to the surfaces and after 24 hours storage and thermocycling $\left(500\right.$ cycles, $\left.5-500^{\circ} \mathrm{C}\right)$, shear bond strength was tested with a universal testing machine and mode of failure was evaluated by a stereomicroscope. Data was analyzed by SPSS18 using Anova, tukey and fisher's exact test. $\mathrm{P}<0.05$ was considered as the level of significance.

Results: The shear bond strength of Teric N-Bond was significantly higher than SE Bond $(P=0.012)$, AdheSE $(P=0.000)$, AdheSE One $F(p=0.001)$ and Adper Prompt L-Pop $(P=0.001)$. Shear bond strength of Single Bond 2 was significantly higher than AdheSE( $P=0.004)$, AdheSE One $F(P=0.006)$ and Adper Prompt $L-P o p(P=0.006)$. Mode of failure in all groups was mostly adhesive.

Conclusion: The shear bond strength of etch-and-rinse adhesive systems were higher than self-etch adhesives except for one adhesive (SE bond) and the bond strength of self-etch adhesives were not significantly different.

Keywords: Primary teeth; Shear bond strength; Adhesive; Etch and rinse; Self etch

\section{Introduction}

Investigations for finding an ideal material for teeth restoration lead to significant progress in restorative materials and their applying methods. Composites and adhesives are two important progresses in dentistry. Today composite restorative materials have common clinical applications. The reasons for wide and increasing application of composites are their conservative tooth preparation, good physical properties, esthetics and also their improvement in adhesive capability to tooth tissues. Adhesive materials which have higher bond to enamel and dentin is preferred because of longer clinical performance $[1,2]$. Different adhesive systems are introduced for bonding to tooth structures. The present adhesive systems are divided to etch-and-rinse and self-etch [2].

The etch-and-rinse systems are divided to two or three step techniques that have separate acid etch step with $32-37 \%$ phosphoric acid. In three-step etch-and-rinse systems, primer and adhesive are applied in separate steps. In two-step etch-and-rinse adhesives, primer and adhesive resin are combined in one solution and are used after etching enamel and dentin. These systems are technique sensitive and time consuming. Etch, rinse and drying steps are important and caused their technique sensitivity. Self adhesive systems are introduced to simplify clinical steps, reduce technical sensitivity, decreased clinical mistakes and reduced clinical chair time. Self-etching systems in form of self-etching primers, etch enamel and dentin simultaneously, infuse into micromechanical pores, and then adhesive resin is applied. In "all in one" self-etching systems, acidic primer and adhesive are combined with each other and applied in one step [2-4].

In pediatric dentistry, it is very important to decrease chair time and clinical steps because of inadequate coordination of children with dentist in ways such as using self-etch adhesives and elimination of etching, rising and drying steps.

In clinical success of adhesive material, the bond strength is very important. The high bond strength helps adhesive to resist against stresses caused by resin contraction and forces which are applied in area between tooth and restoration. For longer time and thus later bond failure and its problems such as recurrent caries, tooth sensitivity and restoration failure [5].

The shear bond strength is one type of tests used for evaluating bond strength. The shear bond strength (SBS) is the maximum force which adhesive joint can tolerate before fracture. This force is applied to adhesive area between two materials [6]. 
Because of the differences in primary and permanent enamel structure, their bonding characteristics are not the same. Most of the studies in comparing different adhesive systems were done on enamel structure of permanent teeth and not primary teeth. The aim of this study was to evaluate shear bond strength of six different adhesive system applied on enamel of deciduous teeth from 72 human teeth.

Six adhesive systems including two Step etch-and-rinse adhesives, Tetric N-Bond (IvoclarVivadent,Schaan, Liechtenstein) and Single Bond 2 (3M, ESPE, St.Paul, MN, USA), two type of two step self-etch adhesives, AdheSE (IvoclarVivadent, EtsSchaan Liechtenstein) and SE Bond (Kurary, Tokyo, Japan) and two type of one-step self-etch adhesives, Adper Prompt L-Pop (3M, ESPE, St.Paul, MN, USA) and AdheSE One F (IvoclarVivadent, EtsSchaan Liechtenstein) on enamel of primary teeth. The null hypothesis was there were not significant differences in shear bond strength between these six adhesives.

\section{Material and Method}

This experimental study was performed on 72 extracted first and second primary molars, which had intact buccal and lingual surfaces without any decay, cracks or defects. Teeth were cleaned up of soft tissues and debries, and they were kept in $0.5 \%$ chloramine-T solution (Fisher chemical, Fair lawn, NJ, USA) for 24 hours, and then in water and also in room temperature.

Byusing a diamond fissure bur (Tizkavan, Iran) buccalor lingual enamel surfaces were freshen under air-water coolant spray to reach a smooth surface which were checked by a surreyour's perpendicular rod. The teeth were mounted in self-cure acrylic resin (Acropars,Marlic Co., Iran) up to CEJ region, with the help of a surveyor vertical barin the way that enamel smooth surface were placed perpendicular to the horizon. The teeth were randomly divided into six groups (A to $\mathrm{F}, \mathrm{n}=12$ each group representing one adhesive system). Table 1 show the materials used in this study.

The bonding steps and composite adhesion were performed as follow according to manufactures' instruction:

Group A: Enamel was etched with phosphoric acid 35\% (Ivocalrvivadent, Schaan, Leichtenstein) for 20 seconds and then it was washed for 30 seconds and was dried by a cotton bullet one layer of Tetric N-Bond (IvoclarVivadent, Schaan, Liechtensteien) was applied on enamel for 10 seconds, thinned with air pressure, and then cured with a Quartz-Tungsten-Halogen light cure device Coltolux75(ColteneWhaledent, USA) with the $600-650 \mathrm{~mW} / \mathrm{cm}^{2}$ intensity for 20 seconds. The intensity of the curing device was measured periodically with radiometer (Optilux, SdS, Kerr).

Group B: The primer ofAdheSE(IvoclarVivadent, Schaan, Liechtenstein) was applied on enamel for 30 seconds, and its excess was thinned with strong pressure of air, then adhesive AdheSE was placed on enamel surface for 20 seconds, air driedand was cured for 20 seconds.

\begin{tabular}{|c|c|c|c|}
\hline Materials & Type & Composition & Manufacturer \\
\hline $\begin{array}{l}\text { Tetric } \mathrm{N} \text { - } \\
\text { Bond }\end{array}$ & $\begin{array}{l}\text { Etch-and- } \\
\text { rinse adhesive }\end{array}$ & $\begin{array}{l}\text { HEMA, Bis GMA, urethane dimethacrylates, phosphonic acid acrylate, Ethanol }(<20 \% \mathrm{wt}) \text {, nano-filler }\left(\mathrm{Sio}_{2}\right)(<1 \% \\
\text { wt), film-forming agent, Catalysts and stabilizers }\end{array}$ & $\begin{array}{l}\text { IvoclarVivadent, } \\
\text { Schaan, } \\
\text { Liechtenstein }\end{array}$ \\
\hline AdheSE & $\begin{array}{l}\text { Two-step self- } \\
\text { etch adhesive }\end{array}$ & $\begin{array}{l}\text { Primer: dimethacrylate, phosphonic acid acrylate, initiators and stabilizers in an aqueous solution. } \\
\text { Bonding: HEMA, dimethacrylate, silicon dioxide, initiators and stabilizers. }\end{array}$ & $\begin{array}{l}\text { IvoclarVivadent, } \\
\text { Schaan, } \\
\text { Liechtenstein }\end{array}$ \\
\hline $\begin{array}{l}\text { AdheSE } \\
\text { One F }\end{array}$ & $\begin{array}{l}\text { Self-etch } \\
\text { adhesive }\end{array}$ & $\begin{array}{l}\text { Derivates of bis-acrylamide, water, bis-methacrylamidedihydrogen phosphate, alcohol, amino acid acrylamide, } \\
\text { hydroxy alkyl methacrylamid, alkyl sulforic acid acrylamide, highly dispersed silicon dioxide, initiators, stabilizers } \\
\text { and potassium fluoride }\end{array}$ & $\begin{array}{l}\text { IvoclarVivadent, } \\
\text { Schaan, } \\
\text { Liechtenstein }\end{array}$ \\
\hline $\begin{array}{l}\text { Single } \\
\text { Bond } 2\end{array}$ & $\begin{array}{l}\text { Etch-and- } \\
\text { rinse adhesive }\end{array}$ & $\begin{array}{l}\text { BisGMA, HEMA, dimethacrylates, ethanol, water, a novel photoinitiator system and a methacrylate functional } \\
\text { copolymer of polyacrylic and polyitaconic acids }\end{array}$ & $\begin{array}{l}\text { 3M, } \quad \text { ESPE, } \\
\text { St.Paul, MN, USA }\end{array}$ \\
\hline SE Bond & $\begin{array}{l}\text { self etch } \\
\text { adhesive }\end{array}$ & $\begin{array}{l}\text { Primer: MDP, HEMA, hydrophilic dimethacrylates, N,N-diethanol p-toluidine, } \mathrm{CQ} \text {, water } \\
\text { Band: } \mathrm{MDP}, \mathrm{HEMA} \text {, Bis-GMA, hydrophobic dimethacrylates, silanated colloidal silica, N,N-diethanol p-toluidine, } \\
\mathrm{CQ}\end{array}$ & $\begin{array}{l}\text { Kuraray, Tokyo, } \\
\text { Japan }\end{array}$ \\
\hline $\begin{array}{l}\text { Adper } \\
\text { Prompt L- } \\
\text { Pop }\end{array}$ & $\begin{array}{l}\text { self etch } \\
\text { adhesive }\end{array}$ & $\begin{array}{l}\text { Liquid 1: Methacrylated phosphoric esters } \\
\text { Bis-GMA, Initiators based on camphorquinone } \\
\text { Stabilizers } \\
\text { Liquid 2: Water, 2-Hydroxyethyl methacrylate (HEMA), Polyalkenoic acid, Stabilizers }\end{array}$ & $\begin{array}{l}\text { 3M, } \quad \text { ESPE, } \\
\text { St.Paul, MN, USA }\end{array}$ \\
\hline Z 250 & $\begin{array}{l}\text { Light cure } \\
\text { composite }\end{array}$ & $\begin{array}{l}\text { Bis-GMA, UDMA andBis-EMA; } \\
\cdot 66 \% \text { of filler: Zirconium/ Silica }\end{array}$ & $\begin{array}{l}3 \mathrm{M}, \quad \text { ESPE, } \\
\text { St.Paul, MN, USA }\end{array}$ \\
\hline N-Etch & etchant & $37 \%$ Phosphoric acid, thickeners and pigments & $\begin{array}{l}\text { IvoclarVivadent, } \\
\text { Schaan, } \\
\text { Liechtenstein }\end{array}$ \\
\hline
\end{tabular}

Table1: Materials used in this study

Group C: AdheSE One F adhesive (IvoclarVivadent, EtsSchaan, Liechtenstein) was applied on enamel surface for 20 seconds, then with strong pressure of air its excess was removed, and finally it was cured for 20 seconds. 
Group D: Enamel was etched by phosphoric acid 35\% for 15 seconds then it was washed for 10 seconds, dried by a cotton bullet. Then immediately 2-3 layers of Single Bond 2 (3M, ESPE, St.Paul, MN, USA) were applied on enamel for 15 seconds. In next step mild air pressure was applied and bonding was cured for 20 seconds.

Group E: The Primer of SE Bond (Kurary, Tokyo, Japan) was applied on enamel surface for 20 seconds, and it was dried with mild air pressure. Then SE Bond adhesive was placed on enamel surface and thinned with gentle air pressure. Finally it was cured for 20 seconds.

Group F: Adper Prompt L-Pop (3M, ESPE, St.Paul, MN, USA) which was uni-does type was applied according to manufacturer's instruction with a brush on enamel for 15 seconds. Then it was gently air dried and cured for 20 seconds.

Composite (Z250, shade: A1, 3M, ESPE, St. Paul , MN, USA) was placed on bonded enamel surface in two increments using a clear plastic cylindrical mold with internal diameter of $2 \mathrm{~mm}$ and height of $3 \mathrm{~mm}$. Each layer was cured for 20 seconds. Then plastic mold was removed and composite was cured for 40 seconds again. The samples were stored in $37^{\circ} \mathrm{C}$ waterfor 24 hours and then thermocycled $(500$ cycles between $5-55^{\circ} \mathrm{C}$ with a 30 second dwell time and a transfer time of 10 seconds) with a thermocycling machine (BaradaranPoya, Iran).

The samples were placed in Testomeric machine (Testomeric, M350-10CT, England) and the bonding surface of tooth was parallel to device chisel-shape blade. The blade was placed in composite-enamel interface, and force was applied tosamples with the cross-head speed of $0.5 \mathrm{~mm} / \mathrm{min}$ and with the load cell of $50 \mathrm{kgf}$, when break down was occurred.

The force needed to breakdown each samples was recorded in Newton and converted to megapascal (MPa) with below equation:

Shear bond strength (MPa): Peak load in break zone (Newton)/ bond surface $\left(\mathrm{mm}^{2}\right)$

Mode of failure of each sample was observed with stereomicroscope (Olympus, DP12, Germany) with 40X magnification.

Cohesive failure in enamel (90-100\% of failure was in enamel) 2 Adhesive failure (failing in bonded interface): $90-100 \%$ of the bonded interface failed. 3- Cohesive failure in composite $(90-100 \%$ of the failure was in composite). 4- Mixed failure (partially adhesive and partially cohesive).

SPSS v18 was used to evaluate and analyze the data. The significant level was considered 0.05 in all calculations. After checking the normality of the data with Kolmogrov-Smirnov test, Two- way ANOVA and Tukey, HSD were used. For assessing "Mode of failure", fisher's exact test was used.

\section{Results}

Results were summarized in Table 2. There were significant differences between groups ( $\mathrm{P}=0.000)$. The difference between Tetric N-Bond and Single Bond 2 was not statistically significant $(p=0.191)$. The mean SBS of Tetric N-Bond was significantly higher than AdheSE $(\mathrm{p}=0.000)$, AdheSE One $\mathrm{F}(\mathrm{p}=0.001)$, SE Bond $(\mathrm{p}=0.012)$ and Adper Prompt L-Pop $(p=0.001)$. The mean of SBS of Single Bond 2 was significantly higher than AdheSE $(\mathrm{p}=0.004)$, AdheSE One $\mathrm{F}(\mathrm{p}=0.006)$, and Adper Prompt L-Pop ( $\mathrm{p}=0.006)$. The difference between Single Bond 2 and SE Bond was not statistically significant $(\mathrm{p}=0.099)$. There were not significant differences among self-etch groups. Adhesive failure was the most common mode of failure (Table 3 ).

\begin{tabular}{|l|l|l|l|}
\hline Group & N & $\begin{array}{l}\text { Mean } \\
(\mathbf{M P a})\end{array}$ & Standard Deviation (SD) \\
\hline Tetric N-Bond & 12 & $23.362^{\mathrm{a}}$ & 3.65 \\
\hline AdheSE & 12 & $17.540^{\mathrm{b}}$ & 2.84 \\
\hline AdheSE One F & 12 & $17.69^{\mathrm{b}}$ & 3.04 \\
\hline Single Bond 2 & 12 & $21.54^{\mathrm{a}, \mathrm{c}}$ & 2.21 \\
\hline SE Bond & 12 & $18.81^{\mathrm{b}, \mathrm{c}}$ & 4.26 \\
\hline Adper Prompt L-Pop & 12 & $17.39^{\mathrm{b}}$ & 3.29 \\
\hline Total & 72 & 19.59 & 3.97 \\
\hline
\end{tabular}

Table 2: Comparison of SBS of six adhesives to enamel of primary tooth

\begin{tabular}{|c|c|c|c|c|c|}
\hline \multicolumn{2}{|l|}{ Group } & \multicolumn{4}{|l|}{ Mode of failure } \\
\hline & & \multirow{3}{*}{$\begin{array}{l}\text { Cohesive enamel } \\
\text { Count }(\%) \\
1(8.3 \%)\end{array}$} & \multirow{3}{*}{$\begin{array}{l}\text { Cohesive composite } \\
\text { Count(\%) } \\
0(0 \%)\end{array}$} & \multirow{3}{*}{$\begin{array}{l}\text { Adhesive } \\
\text { Count(\%) } \\
7(58.3 \%)\end{array}$} & \multirow{3}{*}{$\begin{array}{l}\text { Mix } \\
\text { Count(\%) } \\
4(33.3 \%)\end{array}$} \\
\hline & & & & & \\
\hline Tetric N-Bond & & & & & \\
\hline AdheSE & Count & $0(0.0 \%)$ & $0(0 \%)$ & $9(75 \%)$ & $3(25 \%)$ \\
\hline AdheSE One F & Count & $0(0.0 \%)$ & $0(0 \%)$ & $8(66.66 \%)$ & $4(33.33 \%)$ \\
\hline Single Bond 2 & Count & $0(0.0 \%)$ & $0(0 \%)$ & $7(58.3 \%)$ & $5(41.7 \%)$ \\
\hline SE Bond & Count & $2(16.66 \%)$ & $0(0 \%)$ & $8(66.66 \%)$ & $2(16.66 \%)$ \\
\hline Adper Prompt L-Pop & & $0(0.0 \%)$ & $0(0 \%)$ & $11(91.66 \%)$ & $1(8.33 \%)$ \\
\hline Total & & $3(4.91 \%)$ & $0(0 \%)$ & $43(70.49 \%)$ & $15(24.59 \%)$ \\
\hline
\end{tabular}

Table 3: The mode of failure in six adhesives 


\section{Discussion}

Restoration in mouth is exposed to different forces. During composite polymerization, resin contraction induces stress in bonded area and pulls it from cavity walls. Stresses caused by chewing and thermal and chemical situations can affect the quality of bond [6]. Bond strength tests evaluate adhesive potential in resisting against these stresses during services.

The aim of this study was to evaluate SBS of composites to enamel with using different etch-and-rinse and self-etch adhesives. The null hypothesis was rejected in some parts. The highest SBS to enamel of primary tooth in this study belongs to Tetric N-Bond adhesive.

Research reported that SBS to enamel of primary teeth are less than permanent teeth. Higher density, more regular structure of enamel in permanent tooth and presence of specific direction and higher number of enamel prisms and higher crystal density in permanent teeth compared with primary teeth are the reasons [7].

We did not find significant difference in SBS of two studied etchand- rinse adhesives and SBS of Tetric N-Bond was higher than selfetch adhesives. The SBS of Single Bond 2 was higher than all self-etch adhesives except SE Bond. Tetric N-Bond and Single Bond 2 are ethanol-based adhesives with similar technique sensitivity which can explane the present result.

The results of present study are similar to some other studies which compared self-etch and etch-and-rinse adhesive systems [8-10]. According to one SEM study, resin tags which formed in enamel after self-etch adhesives' application was lesser and with lower depth of penetration in comparison with etch-and-rinse adhesives [11]. Another SEM analysis in enamel showed that the depth of echant penetration and resin infiltrations are directory related with bond strength [12].

According to the results of this study, there were not significant differences in SBS between self-etch adhesives.

Generally self-etch adhesives are divided in three groups based on their acidity level; mild $(\mathrm{pH}>2)$, moderate $(1<\mathrm{pH}<2)$ and strong $(\mathrm{pH}<1)$ [13]. Enamel etching by self-etch adhesives depends on adhesive's $\mathrm{pH}$. The lower the $\mathrm{pH}$, the higher enamel etching capacity. Etching effects of self-etch adhesives on enamel surface has important role in strength of bond to enamel $[14,15]$.

pHs of self-etch adhesives examined in this study, are 2(SE. Bond), 1.5 (AdheSE), 1.4 (AdheSE one F) and 0.8 (Prempt 1-pop). But according to Ebrahimi et al. study, the different acidity of self-etch adhesives necessarily does not cause higher amount of bond strength to enamel and for better interaction between self-etch adhesives and enamel, it was recommended to apply them on cutted enamel and also use phosphoric acid for few seconds before [16].

The other factors that affect SBS of self etch adhesives, besides acidity included type of solvent, type of functional monomer, presence of filler and technical sensitivity [14]. The most common solvents are ethanol, acetone and water. The high steam pressure of acetone is its main advantage. In some of self etch adhesives acetone is with water. The ethanol higher steam pressure compared with water cause better evaporation of ethanol by air drying.

Water is part of self adhesives used for ionization of acidic monomers. Since water boiling temperature is high and its steam pressure is low, removing water from tooth surface after its application is hard. Molecules like HEMA reduce water steam pressure which may also interrupt removing water. Excessive water decrease bond strength of adhesives by forming water blisters, dilute the primer which reduce it its effects. Furthermore, excessive water prevents optimum polymerization of adhesives [17].

For strengthening of adhesive layer, fillers are added fillers prevent thinning of adhesive layer, the thin adhesive layer by forming oxygen inhibition layer cause incomplete resin polymerization; also the thin adhesive layer cannot resist contraction forces during polymerization, and break from inside (adhesive failure). On the other hand adhesives with filler have less contraction inside themselves [17,18]. Some studies reported higher bond strength for adhesives with filler [14,15], while others stated no differences $[19,20]$. In present study SE Bond (with 10\% filler), AdheSE (with 2\% filler), and AdheSE One F (with less than 5\% filler) are adhesives with filler, and Adper Prompt L-Pop is from adhesives without filler [21].

In two-step self-etch adhesives, application of hydrophobic resin layer can cause higher bond strength than one-step self-etch adhesives [22]. In addition this adhesive has 10-MDP functional monomer which provides stable chemical bond with hydroxyapatitie and increase resistance against hydrolytic failure [23]. 10-MDP is an etching monomer from di-hydogen phosphate group that is separatedin water and produce two protons. Yoshida showed that this monomer is able to make a strong ionization bond with calcium [24]. In present study the difference between SBS of Single Bond 2 and SE Bond was not significant. Some other studies reported similar results $[25,26]$.

In our study the SBS of Adper Prompt L-Pop to primary tooth enamel compared with other studied adhesive did not have significant difference. Adper Prompt L-Pop is a one-step adhesive with high concentration of phosphoric acid ester methacrylate (80\%). Its $\mathrm{pH}$ is 0.8 and has strong etching power. Some studies showed that its acidic property is high enough to produce etching pattern similar to phosphoric acid $32-40 \%$ [18]. This acidity induce rough etch pattern in enamel.

2-metacryloyloxyethyl-dihydrogen-phosphate is hydrolytically unstable and breaks down in a water solution to HEMA and phosphoric acid which cause its acidic property. Adper Prompt L-Pop produce apparent demineralization pattern in enamel and dentin. This adhesive have polyalkenoic copolymer which stabilize it in moist. Of course the role of this compound in bond strength is unclear [27].

In present study the dominant type of mode of failure in all the groups was adhesive. It was reported in studies that in adhesive systems with lower bond strength, the mode of failure is mainly adhesive, while cohesive and mix modes of failure are occur in systems with higher bond strength $[28,29]$. On the other hand, they are studies which stated that mode of failure is not related with bond strength $[30,31]$.

\section{Conclusion}

The shear bond strength of etch and rinse adhesives (Tetric NBond and Single bond 2) were significantly higher than self-etch except for Single Bond and SE Bond adhesives, which deference was not significant, and the shear bond strength of self-etch adhesives were not significantly different. 
Citation: Gisovar EF, Hedayati N, Shadman N, Shafiee L (2014) Comparing the Shear Bond Strength of Six Adhesive Systems to Enamel of Primary Teeth. Dentistry 4: 269. doi:10.4172/2161-1122.1000269

Page 5 of 5

\section{References}

1. Heyman HO, Ritter AV, Roberson TM (2013) Introduction to composite restorations. In: Roberson TM, Heyman HO, Swift E. Sturdevant's Art and Science of operative dentistry. St.Louis: Mosby Elsevier 6: 216-228.

2. Perdigao J, Swift E, Walter R (2013) Fundamental concepts of enamel and dentin adhesion. In: Roberson TM, Heyman HO, Swift E. Sturdevant's Art and Science of operative dentistry. St.Louis: Mosby Elsevier 6: 114-140.

3. Gupta N, Kathuria N, Mehtal K (2011) Bonding: foundation of dentistry. J Innovative Dent 1: 60-65.

4. Summit JB, Robins JW, Hilton TJ, Schwartz RS (2006) Fundamentals of operative dentistry. Quintessence 3: 183-258.

5. Van Meerbeek B, De Munck J, Yoshida Y, Inoue S, Vargas M, et al. (2003) Buonocore memorial lecture. Adhesion to enamel and dentin: current status and future challenges. Oper Dent 28: 215-235.

6. Powers JM, Sakaguchi RL (2006) Craig's restorative dental material St.Louis: Mosby Elsevier 12: 51-96.

7. Miranda C, Prates LH, Vieira Rde S, Calvo MC (2006) Shear bond strength of different adhesive systems to primary dentin and enamel. J Clin Pediatr Dent 31: 35-40.

8. Yazici AR, Celik C, Ozgünaltay G, Dayangaç B (2007) Bond strength of different adhesive systems to dental hard tissues. Oper Dent 32: 166-172.

9. Paradella TC, Fava M (2007) Bond strength of adhesive systems to human tooth enamel. Braz Oral Res 21: 4-9.

10. El Zohairy AA, Saber MH, Abdalla AI, Feilzer AJ (2010) Efficacy of microtensile versus microshear bond testing for evaluation of bond strength of dental adhesive systems to enamel.Dent Mater 26: 848-854.

11. Hashimoto M, Ohno H, Yoshida E, Hori M, Sano H, et al. (2003) Resinenamel bonds made with self-etching primers on ground enamel. Eur J Oral Sci 111: 447-453

12. Glasspoole EA, Erickson RL, Davidson CL (2001) Effect of enamel pretreatments on bond strength of compomer. Dent Mater 17: 402-408.

13. Beloica M, Goracci C, Carvalho CA, Radovic I, Margvelashvili M, et al. (2010) Micro tensile vs microshear bond strength of all-in-one adhesives to unground enamel. J Adhes Dent 12: 427-433.

14. Yazici AR, Yildirim Z, Ertan A, Ozgunaltay G, Dayangac B, et al. (2012) Bond strength of one-step self-etch adhesives and their predecessors to ground versus unground enamel. Eur J Dent 6: 280-286.

15. Lopes GC, Marson FC, Vieira LC, de Caldeira AM, Baratieri LN (2004) Composite bond strength to enamel with self-etching primers. Oper Dent 29: 424-429.

16. Ebrahimi SF, Shadman N, Abrishami A (2013) Effect of ferric sulfate contamination on the bonding effectiveness of etch-and-rinse and selfetch adhesives to superficial dentin. J Conserv Dent 16: 126-130.
17. Van Landuyt KL, Snauwaert J, De Munck J, Peumans M, Yoshida Y, et al. (2007) Systematic review of the chemical composition of contemporary dental adhesives. Biomaterials 28: 3757-3785

18. Stockton LW, Tsang ST (2007) Microleakage of Class II posterior composite restorations with gingival margins placed entirely within dentin. J Can Dent Assoc 73: 255.

19. Braga RR, Cesar PF, Gonzaga CC (2000) Tensile bond strength of filled and unfilled adhesives to dentin. Am J Dent 13: 73-76.

20. Gallo JR, Comeaux R, Haines B, Xu X, Burgess JO (2001) Shear bond strength of four filled dentin bonding systems. Oper Dent 26: 44-47.

21. Atash R, Van den Abbeele A (2005) Bond strengths of eight contemporary adhesives to enamel and to dentine: an in vitro study on bovine primary teeth. Int J Paediatr Dent 15: 264-273.

22. Pashley DH, Tay FR (2001) Aggressiveness of contemporary self-etching adhesives. Part II: etching effects on unground enamel. Dent Mater 17: 430-444.

23. Abdalla AI, El Zohairy AA, Abdel Mohsen MM, Feilzer AJ (2010) Bond efficacy and interface morphology of self-etching adhesives to ground enamel. J Adhes Dent 12: 19-25.

24. Yoshida Y, Nagakane K, Fukuda R, Nakayama Y, Okazaki M, et al. (2004) Comparative study on adhesive performance of functional monomers. J Dent Res 83: 454-458.

25. Nagayassu MP, Shintome LK, Arana-Chavez VE, Fava M (2011) Microshear bond strength of different adhesives to human dental enamel. J Clin Pediatr Dent 35: 301-304.

26. Marquezan M, da Silveira BL, Burnett LH Jr, Rodrigues CR, Kramer PF (2008) Microtensile bond strength of contemporary adhesives to primary enamel and dentin. J ClinPediatr Dent 32: 127-132.

27. Nematianaraki S, Banav S, Valaee N, Korkeabadi H (2010) Comparing the effect of three self-etching bondings on human dentin shear bond strength and micro leakage. JRDS 7: 30-33.

28. Gateva N, Dikov V(2012) Bond strength of self etch adhesives with primary and permanent teeth dentin- in vitro study. JIMAB 18: 168-173.

29. Perdigão J, May KN Jr, Wilder AD Jr, Lopes M (2000) The effect of depth of dentin demineralization on bond strengths and morphology of the hybrid layer. Oper Dent 25: 186-194.

30. Tezvergil A, Lassila LV, Vallittu PK (2005) The shear bond strength of bidirectional and random-oriented fibre-reinforced composite to tooth structure. J Dent 33: 509-516.

31. O'Keefe KL, Pinzon LM, Rivera B, Powers JM (2005) Bond strength of composite to astringent-contaminated dentin using self-etching adhesives. Am J Dent 18: 168-172. 